\section{Quality Practices, Corporate Social Responsibility and the "Society Results" Criterion of the EFQM Model}

\author{
María de la Cruz del Río-Rama \\ University of Vigo, Department of Business \\ Organization and Marketing, Ourense, Spain \\ José Álvarez-García \\ José Luis Coca-Pérez \\ University of Extremadura, Department of Financial \\ Economics and Accounting, Cáceres, Spain
}

Received on

02/26/2016

Approved on

$11 / 08 / 2016$

\section{Responsible editor:}

Prof. Dr. João Maurício Gama

Boaventura

Evaluation process:

Double Blind Review

\begin{abstract}
Purpose - The purpose of this research is to analyze whether quality management practices implemented and carried out by the rural accommodation establishments under study influence society results obtained by organizations, which are understood as the participation therein and the development of local community.
\end{abstract}

Design/methodology/approach - The working methodology consists of carrying out an exploratory and confirmatory factor analysis in order to test the psychometric properties of measurement scales, and the hypothesized relationships between critical factors and society results are examined using structural equation modeling.

Findings - The study provides evidence of a weak relationship between the critical factors of quality and society results in rural accommodation establishments. The results suggest that process management is the only quality practice that has a direct effect on society results and the rest of the critical factors are considered antecedents of it.

Originality/value - The contribution of this study, which explores the impact of the critical factors of quality on society results, is to confirm that there is an effect of the critical factors of quality on society results (social and environmental responsibilities) through the direct relationship of process management. Very few studies examine this relationship.

Keywords - Quality management; Critical factors; Society results; Rural accommodations establishments.

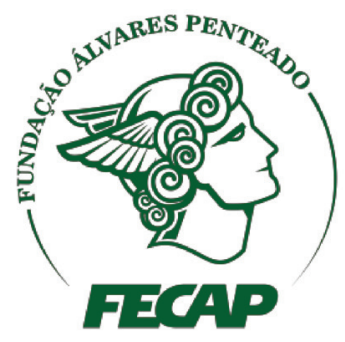

Review of Business Management

DOI: $10.7819 /$ rbgn.v0i0.3026 


\section{Introduction}

In the current context, both industrial and service companies seek to obtain better financial and economic results through the implementation of Quality Management Systems (TQM). There are many studies that have already demonstrated empirically the ability of TQM to improve these results directly and indirectly through improved management of organizations supported by Quality Assurance Systems, like ISO 9001, or excellence models, like the European Excellence Model (EFQM).

These quality systems allow for better internal management of organizational performance, which leads to obtaining important benefits, among which we can mention: achieving greater efficiency in its operations and therefore, boosting efficiency (ALNasser, Yusoff, \& Islam, 2013; Chang, Chiu, \& Chen, 2010), improving productivity (Hassan, \& Kerr, 2003), improving strategic performance (Al-Tarawneh, 2010; Zhang, Waszink, \& Wijngaard, 2000), gaining and maintaining a competitive advantage (Talib, Rahman, \& Qureshi, 2013), among others.

Companies are also aware of the usefulness of these models to generate and maintain longterm competitive advantages and thus increase or maintain their financial results by integrating the concept of sustainable development in their management (Norris, \& O'dwyer, 2004). This concept is based on the triple objective which a company should pursue, according to Elkington (1997): to be economically viable, socially beneficial and environmentally responsible. Total Quality Management (TQM) models, created from the principles of total quality management, integrate, among others, Corporate Social Responsibility (CSR), which pursues to combine economic activities with the social and environmental concerns of all stakeholders.

In this sense, Tarí and García (2011) state that companies with quality systems can adopt environmental (Marimon Viadiu, Casadesús $\mathrm{Fa}, \&$ Heras Saizarbitoria, 2006) and social
(McAdam, \& Leonard, 2003; Withanachchi et al., 2007) aspects more easily and quality management practices help develop social responsibility elements. There are many who believe that excellence models, such as the EFQM Model, are an important tool for companies wishing to adopt the philosophy of Corporate Social Responsibility (Pedersen, \& Neergaard, 2008; Robson \& Mitchell, 2007), in which the impact of the enabler criteria (leadership, policy and strategy, partnerships and resources, people management) on society results (which includes two of the areas that make up the corporate social responsibility: social objectives of the enterprise and environmental responsibility) is taken into account.

The EFQM model does not show explicitly the relationship between the critical factors of quality implemented and society results. These relationships should be studied, and they are a gap in the scientific literature.

Considering the above, the purpose of this research is to analyze whether quality management practices implemented and carried out by the rural establishments under study influence society results, which will allow establishment managers to know on which critical factors or quality practices they should focus their efforts, in order to implement necessary actions to achieve these improved results (development of environmental policies, labor risks, participation in community activities, setting goals in this context and analyzing their results, etc., and on the other hand, see if results improve over time). Undoubtedly, the implementation of all these mechanisms will lead to greater satisfaction of society in this area, with the company's commitment to social responsibility dimensions.

The work is divided into six sections. In the introduction, the subject matter is contextualized and the work objective is presented. In the second section, a review of the literature on critical factors of quality management (CSFs), the relationship of critical factors in the EFQM model with the concept of social responsibility, which we 
understand, in our research, as Society results, and the Theoretical Model and Hypotheses are presented. In the third section, the methodology used is described and the measurement scale is validated. In the fourth section, analysis data is collected, and in the last two sections, results are discussed and conclusions are presented together with the limitations of the research.

\section{Literature review}

\section{I Critical success factors (CSFs) of quality management}

The first research conducted to determine the critical factors of quality was by Saraph, Benson and Schroeder (1989), whose objective was to develop and empirically validate an instrument for measuring quality practices, obtaining a set of eight critical factors of quality management, derived from the literature review published by the gurus of quality. These were the authors who first defined what is meant by critical success factors (CSFs) for TQM "as critical areas of managerial planning and action that must be practiced to achieve effective quality management in the business unit" (Saraph et al., 1989, p. 811).

This line of research has been followed in the past 20 years by numerous studies (Ahire, Golhar, \& Waller, 1996; Fotopoulos \& Psomas, 2009; Sadikoglu \& Zehir, 2010) that approached the problem using different methodologies and replicating the instrument in different cultures and countries. However, to this day, there is no consensus about what the critical factors of quality are (Singh, Feng, \& Smith, 2006) and the statement by Zairi (1996) is still valid. One of the main difficulties in studying the critical factors of TQM is how to define and measure them.

In recent years, researchers have conducted reviews on the scientific literature in an attempt to collect the CSFs (Hietschold, Reinhardt, \& Gurtner, 2014; Magd, 2014; Sila \& Ebrahimpour, 2002), collecting over 56 different factors (Hietschold et al., 2014).

In this sense, Magd (2014), in his study, attempts to collect the critical factors which have been taken into account in recent years. The author groups them into the different existing schools of thought: input from Quality Gurus, Models of Excellence and results of empirical research. Precisely 26 studies were analyzed. Finally, in his study, he concludes that the most common critical factors identified by the gurus of quality and excellence models are: Strategy and Policy Planning; Information and Analysis; People Management; Process Management; Customer Satisfaction Management; Business Results; Performance and Management of Suppliers/ Partners; Impact on Society; Resources Management.

Moreover, of the analysis of critical factors used in empirical research, the following stand out as the most used: top management commitment $\&$ leadership; strategic planning; customer focus and satisfaction; quality information and performance measurement; benchmarking; human resource management $\&$ development; training; employee empowerment and involvement; employee satisfaction; process management; resource management; business results; product and service design; supplier management; continuous improvement; and communication.

In the same year, Hietschold et al. (2014) also reviewed 145 studies, of which 62 were selected according to fixed parameters, 11 basic critical factors were identified, and 511 factors were extracted, which gives us an idea of the dispersion in the definition, measurement and use of CSFs in quality.

In Excellence models and more specifically in the EFQM model, the critical factors of quality that are taken into account are denominated enablers and are defined as "what the organization does and how it does it". These criteria form part of the fundamental assumption of the model:

\footnotetext{
"Satisfaction of customers and employees and obtaining a positive impact on society are achieved through proper leadership of managers in the process of transforming the organization by establishing appropriate policies and
} 
strategies, proper utilization of resources and alliances of all kinds and sound management of their processes all leading to achieve the vision of the organization with excellent business results" (European Foundation for Quality Management [EFQM], 2013).

In our research, we have taken into account those assumptions included in the EFQM model: leadership, personnel management, policy and strategy, process management, learning.

- Leadership: it refers to the responsibility and behavior of the entire management team to manage the company in the process of providing a service according to customer requirements with the aim of satisfying them, as well as promoting all necessary actions for continuous improvement in all service provision processes, ensuring that the management system of the organization is developed and implemented.

- Personnel management: it refers to how the organization manages and develops the skills of the people who constitute it and releases their full potential, both individually and as a team, in the entire organization. It also refers to how the company plans these activities in support of its policy and strategy and the effective performance of its processes.

- Policy and strategy: it refers to how the organization carries out its mission and vision through a clear strategy focused upon its stakeholders, "Customers, Employees, Society and Investors", supported by adequate policies, plans, objectives, goals and processes.

- Process management: it refers to how the organization designs, manages and improves its processes in order to support its policy and strategy, and increasingly create value for its customers and other stakeholders.
- Learning: it is the process through which new skills, abilities, knowledge, behaviors or values are acquired, as a result of studying, experience, training, reasoning and observation.

It is noteworthy that in the EFQM Model as a model of excellence, corporate social responsibility is a transversal concept that appears in each model criterion, and incorporates many of the values and areas worked in CSR.

\subsection{The EFQM Model vs Social Responsibility}

The Comisión de Las Comunidades Europeas (2001) defined CSR as the voluntary integration by companies of social and environmental concerns in their business operations and in their relationship with their partners (stakeholder), giving rise to practices that satisfy them. According to Vidal Vázquez and Soto Rodríguez (2013, p. 1124) in CSR "its management goes beyond the implementation of quality, respect for the environment or prevention of occupational risks; it refers to the voluntary management of all areas of the organization through a socially responsible behavior". Therefore, there are three areas of CSR: economic area (pursuit of maximum profit and value for the shareholder), sociocultural area (pursuit of social objectives of the company) and environmental area (contribution to sustainable development by the company), and the impact of organizations in all three areas is evident.

The EFQM Excellence Model developed by the European Foundation for Quality Management is conceived as a diagnostic tool to identify strengths and areas for improvement in comparison with "Excellence". This model includes the Social Responsibility to be developed by organizations as one of the fundamental concepts of excellence and is transversally present in the different criteria that make up the model (five enablers, what the organization does, and four results, what the organization obtains). Several authors consider that CSR is part of the 
EFQM Model (McAdam \& Leonard, 2003; Robson \& Mitchell, 2007), as on the assumption of the model, the critical quality factors of the organization are managed considering their impact on society, in addition to satisfying all its stakeholders.

In short, it can be stated that Total Quality Management models such as EFQM allow for the development in companies of a management strategy that allows and aims to meet the needs of its stakeholders (customers, employees, shareholders and society), by integrating the CSR principles (Robson \& Michell, 2007) into the model. It is worth mentioning that "creating a sustainable future" is one of the 8 principles on which the EFQM model is based, "excellent organizations have a positive impact on the world around them because they increase their own performance while improving economic, environmental and social conditions of the communities which they have contact with" (EFQM, 2013). In the model, four results criteria are collected, in which the achievements by their stakeholders are measured in three of them (results in people, customers and society) and key results achieved by the company.

In this sense, Escrig (2010) claims that the EFQM model is a tool for organizations wishing to adopt the CSR philosophy, and, in 2004, the EFQM Framework for CSR was developed as a framework for CSR. It is not a new model of excellence, but it is integrated into the existing one, providing a structured approach, in order to manage CSR through guidelines based on outstanding practices at global level. It enables integration of the environmental, social and economic dimensions (European Foundation for Quality Management [EFQM], 2004) into the strategies of organizations.

\subsection{Society results/Corporate social performance}

The results in society are one of the four "results" criteria considered in the EFQM model and are defined "as what the organization is achieving socially at local, national or international level" (EFQM, 2013). As mentioned in the EFQM excellence model, appropriate management of enablers (CSFs of Quality Management) through responsible behavior, enables the achievement of a positive impact on stakeholders, which is part of the concept of Corporate Social Responsibility (CSR). In this model, the impact of the organization on society in the broad sense is taken into account and it seeks to meet the needs of all interest groups by providing value to all stakeholders (customers, employees, suppliers and the community as a whole (EFQM, 2013).

In this criterion, "society results", the active participation and the development of the local community by the organization are evaluated (two of the dimensions of the RSC, socio-cultural and environmental), considering the policies to reduce and prevent risks to health and safety, environmental protection policies, company participation in many community activities and if the results in society show improvements over time. On the other hand, this criterion is also observed, the actions taken by companies aimed at obtaining information enable them to make strategic decisions to improve the perception of society on the impact of their activities on it (the feeling the community has is evaluated through surveys, meetings with authorities, etc.; the results in society show improvements over time; the objectives in this context are established and the results achieved meet the objectives set by the organization; the causes of these results in society are analyzed and plans or actions for improvement are implemented; these results in society are compared with the company's main competitors, and such comparison is favorable to the company or the company is otherwise learning from them).

To achieve them, active participation in activities by the organization as a responsible subject of society is essential (ethical behavior and the dissemination of values in society, dissemination of relevant information to society, wealth creation and impact on the local, national economy ...), involvement in the Community of which it is part and in its various areas (commitment to economic and social development, education and training 
of its members, support to culture and social activities, volunteer work ...), and furthermore, all the activities of the organization should be aimed at reducing, as well as eliminating any inconvenience or harm that the activities carried out in each of the areas that make up the product or service life cycle can cause (Caneda, 2004).

\subsection{Theoretical model and hypotheses}

In this research, to comply with the proposed objective, a structural model (Figure
1) is proposed, in which the proposed causal relationships are collected, that will allow us to analyze the relationship between the critical quality factors considered in this study and society results, understood as "the development of environmental policies, labor risks, participation in community activities, setting goals in this context and analyzing their results, etc., and on the other hand, observing if the results improve over time".

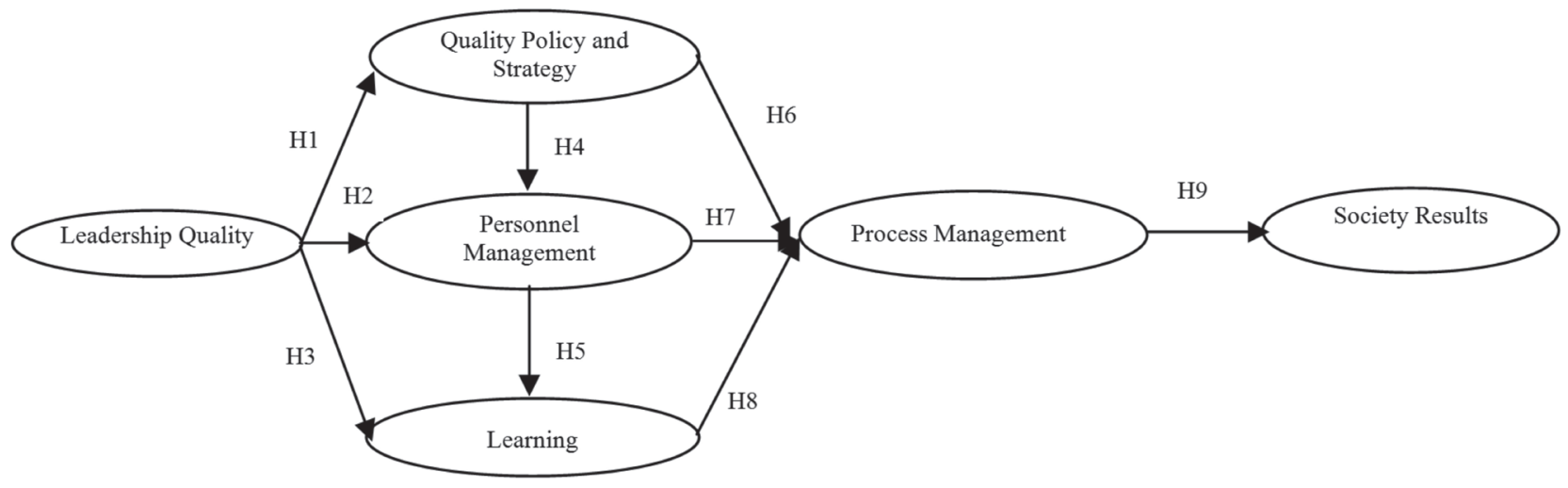

Figure 1. Proposed theoretical model.

The causal relationships posed and hypotheses that support them are presented, considering the literature review prior to the field research carried out. Studies by Saraph et al. (1989), Ahire et al. (1996), Black and Porter (1996), Yusof and Aspinwall (2000) were reviewed, among others. Furthermore, studies taking into account the EFQM excellence model and others like Malcolm Baldrige National Quality Award (Eskildsen \& Dahlgaard, 2000; Pannirselvam \& Ferguson, 2001; Wilson \& Collier, 2000; Winn $\&$ Cameron, 1998) were reviewed.

\subsection{Positive relationship between leadership and quality policy and strategy, personnel management and learning}

Leadership management is the most important factor to implement and successfully manage the critical factors of quality. This statement is corroborated by the gurus of quality (Deming, 1982; Juran, 1988) and later in studies of empirical nature, such as those by Saraph et al. (1989), Flynn, Schroeder and Sakakibara (1995) and more recently (Lakhal, Pasin, \& Limam, 2006; Yusof, \& Aspinwall, 2000), among others. According to Barrett and Waddell (2001), it is not only important for improved financial performance but also for successful implementation of a quality culture.

Eskildsen and Dahlgaard (2000), in their study, empirically support the statement that leadership determines the management of people and resources (has a positive and significant influence), as well as the definition of the policy and strategy. In this sense, top management is responsible for creating values and goals, and providing the resources to achieve them (Grover, Agrawal, \& Khan, 2006). The leadership approach towards management of employees, resources and 
development of the policy and strategy should be a priority for any organization (Soltani, Li, \& Gharneh, 2005). These statements lead us to pose the following assumptions:

$\mathbf{H}_{\mathbf{1}}$ : Leadership of top management has a positive and significant influence on quality policy and strategy.

$\mathbf{H}_{2}$ : Leadership of top management has a positive and significant influence on personnel management.

$\mathbf{H}_{3}$ : Leadership of top management has a positive and significant influence on learning.

\subsubsection{Positive relationship between quality policy and strategy and personnel management and process management}

There are several studies that show this positive relationship (Black \& Porter, 1996; Eskildsen \& Dahlgaard, 2000; Saraph et al., 1989; Wilson \& Collier, 2000; Win \& Cameron, 1998). Winn and Cameron (1998) make the relationship clear, by stating that the policy and strategy are developed through the deployment of key processes (Samson \& Terziovski, 1999) and people management (Eskildsen \& Dahlgaard, 2000), and therefore, the policy and strategy influence process and people management.

$\mathbf{H}_{4}$ : Quality policy and strategy positively and significantly influence personnel management.

$\mathbf{H}_{\mathbf{6}}$ : Quality policy and strategy positively and significantly affect process management.

\subsubsection{Positive relationship between personnel management and learning and process management}

There is preceding literature discussing the positive relationship between personnel management and process management (Ahire et al., 1996; Ahmad \& Schroeder, 2002; Eskildsen, Kristensen, \& Jørn Juhl, 2002; Wilson \& Collier, 2000). All of them have been based on the perception that all employees must participate and can make important contributions to the management of processes with proper management (Ahire et al., 1996; Eskildsen et al., 2002; Wilson \& Collier, 2000) and required training (teamwork, tools, etc.) of staff.

In this regard, personnel management must focus on achieving development of empowerment (delegate the authority to evaluate, implement and control processes to workers), employee commitment (only achieved by creating a quality culture according to Zhang et al., 2000), etc., that is, getting employees involved in improving processes. Studies by Wilson and Collier (2000), Eskildsen et al. (2002) show how human resource management is positively related to process management.

With regard to the positive relationship with learning, according to Ahmad and Schroeder (2002), the process of quality improvement is an organizational learning process that is based on employees. In this sense, only when employees are trained and have developed their skills, can they be involved in process improvement (Ahire et al., 1996; Rao, Solis, \& Raghunathan, 1999). Studies such as those by Anderson, Rungtusanatham and Schroeder (1994) and Hackman and Wageman (1995) show the relationship between both concepts: learning influences the management of processes. This leads us to propose the following hypotheses:

$\mathbf{H}_{5}$ : Personnel management positively and significantly influences learning.

$\mathbf{H}_{7}$ : Personnel management positively and significantly influences process management.

$\mathbf{H}_{\mathbf{8}}$ : Learning positively and significantly influences process management. 


\subsubsection{Positive relationship between process management and society results}

Process management, in studies, is often positively correlated with performance indicators (Nair, 2006) and in the EFQM Model, process management is the link between enablers and results. Quality as excellence consists not only of achieving key business results, but of achieving results in internal (employees) and external (consumers) customers, as well as in the society of which the companies are part (Nabitz, Severnsm Van Den Brink, \& Jansen, 2001).

It is the company's task to lead and show support to the social responsibility dimension (Rao et al., 1999), promoting initiatives aimed at sustainable development and responsible culture. The work of Eskildsen et al. (2002) shows that improvement in organizational performance is a result of the management made of people and processes, and studies by Holjevac (2008) show that TQM increased social responsibility and ethics. Therefore, we propose the following hypothesis.

$\mathbf{H}_{\mathbf{9}}$ : Process management positively and significantly influences society results.

\section{Methodology}

\section{I Universe and field of study}

The scope of the study is rural accommodation establishments (denominated Rural House) in Spain, which are certified "Quality Tourism Q", unique in the tourism sector in Spain. This certification is awarded by the Spanish Tourism Quality Institute (ICTE), if the company complies with the UNE 183001:2009- Rural Accommodation Requirements for providing the service. It is a norm standardizing an intermediate quality system between Quality Assurance and the EFQM model and it differs from the ISO 9001 assurance system in that, besides containing the minimum requirements for the implementation of a Quality Management System, it also includes the service specifications that the company must implement. Both systems are compatible and complementary.

The database which includes the study population was developed from information collected on the website of ICTE, and comprises 227 certified Rural Houses, whose quality manager was emailed a structured questionnaire (September to December 2012), subsequently contacted by telephone in order to increase the response rate. We obtaining 100 valid questionnaires (response rate $44.05 \%$ ), fully completed and discarding those that were incomplete. The study has a margin of error of $7.48 \%$ for a confidence level of $95 \% Z=1.96$ $\mathrm{p}=\mathrm{q}=0.5$.

With respect to the profile of the sample, $95 \%$ of the accommodations are micro-enterprises (0-9 employees) and the remaining 5\% are smallscale accommodation (10-49 employees), taking into account the classification criteria of the European Commission in its Recommendation C (2003) 422 adopted on 6 May 2003. In addition, 67 establishments have had certification of the UNE 183991: 2009 0-3 years and 33 establishments more than three years.

\subsection{Questionnaire and measurement}

To design the questionnaire to measure each of the critical factors considered, measurement scales created and empirically validated by renowned researchers in the field of quality adapted to the sector (eg. Grandzol, \& Gershon 1998; Powell, 1995; Tarí, Molina, \& Castejón, 2007) were taken into account (see appendix), so that the internal validity of the scale is guaranteed. Before sending the final questionnaire, 20 subjects were selected (managers of the company, the sample and experts in the field of quality management) and we carried out a pretest to confirm its validity and clarity of the questions. The instrument was revised on the basis of their suggestions.

Finally, the questionnaire was divided into two parts. The first part consists of questions 
that collect the data for the profile of the sample (establishment size, standard of quality they have, years in the certification, position of the person surveyed). In the second part, the scales of measurement of each of the critical factors are collected, with 49 items (see Appendix), grouped within 7 critical factors (leadership-8, quality policy/planning-7, personnel management-11, learning-9, process management- 6 and society results-8). A 7-point Likert scale ranging from 1 (not implemented) to 7 (implemented 100\%) is used, and, in the case of society results, items are valued $1-7$, strongly disagree to strongly agree. The results of descriptive findings are listed in Table 1 , and we observed that the mean in each of the items measuring the constructs is very high.

Table 1

Model-related questions (translated from Spanish) and descriptive findings

\begin{tabular}{|c|c|c|c|c|c|c|c|}
\hline $\begin{array}{l}\text { Constructs included } \\
\text { SEM }\end{array}$ & Scale items ${ }^{A}$ & Mean & $(\text { s.d. })^{B}$ & $\begin{array}{l}\text { Constructs included } \\
\text { SEM }\end{array}$ & Scale items ${ }^{A}$ & Mean & $(\text { s.d. })^{\mathrm{B}}$ \\
\hline \multirow[t]{6}{*}{ Leadership } & & & & Learning & & & \\
\hline & LE2 & 5.76 & 1.62 & & LA1 & 5.04 & 1.85 \\
\hline & LE3 & 5.75 & 1.72 & & LA3 & 5.24 & 1.78 \\
\hline & LE4 & 5.29 & 1.88 & & LA4 & 4.84 & 2.04 \\
\hline & LE5 & 5.74 & 1.64 & & LA6 & 4.45 & 1.94 \\
\hline & LE7 & 5.83 & 1.65 & & & & \\
\hline \multirow[t]{6}{*}{$\begin{array}{l}\text { Quality Policy and } \\
\text { Strategy }\end{array}$} & & & & Process Management & & & \\
\hline & PO1 & 5.73 & 1.42 & & & & \\
\hline & $\mathrm{PO} 3$ & 5.70 & 1.72 & & $\mathrm{P} 1$ & 5.36 & 1.56 \\
\hline & PO4 & 4.53 & 1.88 & & $\mathrm{P} 2$ & 5.57 & 1.55 \\
\hline & PO5 & 5.70 & 1.62 & & P3 & 5.73 & 1.38 \\
\hline & PO6 & 5.32 & 1.75 & & $\mathrm{P} 4$ & 5.19 & 1.82 \\
\hline \multirow[t]{7}{*}{ Personnel Management } & & & & Society Results & & & \\
\hline & PM2 & 5.66 & 1.73 & & & & \\
\hline & PM4 & 5.41 & 1.73 & & SR5 & 5.36 & 1.72 \\
\hline & PM6 & 5.12 & 1.62 & & SR6 & 5.23 & 1.75 \\
\hline & PM7 & 5.43 & 1.75 & & SR7 & 5.36 & 1.71 \\
\hline & PM9 & 4.66 & 1.87 & & SR8 & 4.48 & 1.64 \\
\hline & PM11 & 5.17 & 2.06 & & & & \\
\hline
\end{tabular}

Note. ${ }^{\text {A }}$ The items listed in this table have been summarized for ease of presentation and comprehension; ${ }^{\mathrm{B}}$ s.d.: Standard deviation.

\section{$3 \cdot 3$ Data analysis}

To carry out the validation of the measurement models by exploratory factor analysis (EFA), the statistical software SPSS version 19.0, whereas AMOS 20.0 is used to validate the measurement model by confirmatory factor analysis (CFA) and estimation of the model using the Structural Equation Modeling (SEM) technique.

\section{Measurement model validation}

Taking into account the methodological recommendations of Anderson and Gerbing (1988), the psychometric properties of the scales (reliability, validity and dimensionality) are analyzed, with the aim of defining the number of items that will measure each variable. To perform the debugging process of measurement scales, we will follow two phases: of an exploratory (AFE) and a confirmatory (AFC) nature. 
To analyze data reliability, internal consistency (analysis of variances and covariances of test indicators) was examined, that is, the itemtotal correlation of each of the proposed scales is observed and Cronbach's Alpha was verified (1951). Item-total correlation, recommended minimum value 0.3 and Cronbach's a, greater than 0.7 according to Nunnally (1979).

To check the unidimensionality or Discriminant Validity, an Exploratory Factor Analysis (Bagozi \& Baumgartner, 1994) was conducted with varimax rotation and Extraction Method of Maximum Likelihood that allows us to determine which observable variables loaded on which latent variables: explained variance (must be greater than 50\%) and factor loading (loadings lower than 0.3 are considered significant according to Hair, Anderson, Tathaman, \& Black, 1999).

The second phase of the process of debugging scales consisted of subjecting the factor solutions obtained to validation by technical confirmatory factor analysis (reliability, validity and unidimensionality are analyzed again), with the aim of confirming whether the specified model corresponds to reality. Confirmatory Factor Analysis allows us to test the quality of fit of the proposed solution (the quality of fit of the structural measurement model and the overall adjustment of the model are evaluated).

To examine the adjustment of the structural measurement model, the significance of the estimated coefficients is taken into account according to the following parameters: the $t$ value of each normalized indicator must exceed + - 1.96; standardized loading should be approximately 0.7 (Jöreskog \& Söbom, 1993) and the $\mathrm{R}^{2}$ parameter will take the value 0.5 recommended by Sharma (1996). For evaluation of the overall adjustment, three types of indices are taken into account: absolute fit, incremental fit and parsimony.

For the reliability analysis, it was estimated by the coefficient of composite reliability of each construct (it reports internal consistency in the measure of the construct), minimum recommended value of 0.7 and variance extracted (AVE) is recommended to be equal to or greater than the threshold of 0.5 (Hair, Sarstedt, Hopkins, \& Kuppelwieser, 2014). The total amount of the variance of the indicators considered by the latent construct is reported.

\section{Estimation of Structural Equation Modeling (SEM)}

To examine the adjustment of the proposed structural model, the factor loadings of second level $(\beta)$ and the proportion of variance explained $\left(\mathrm{R}^{2}\right)$, indicating the amount of variance of the construct that is explained by the model are analyzed. Firstly, the significance of $(\beta)$ is considered, where value $\mathrm{t}$ of each normalized indicator must exceed +-1.96 . Secondly, the overall adjustment of the model is evaluated, taking into account the following goodness (Joreskog \& Söbom, 1988), which ensures the acceptability of the model from different perspectives: chi-square $(\chi 2)$; comparative fit index (CFI); goodness fit index (GFI); normed fit index (NFI); adjusted goodness fit index (AGFI); robustness mean squared errors of approximation (RMSEA). Recommended values greater than 0.9, according to Hair et al. (1999) and Joreskog and Söbom (1988), for CFI, GFI, NFI and AGFI indices and RMSEA values below 0.08 (Browne $\&$ Cudeck, 1993) are recommended.

\section{Results}

\section{I Measurement model}

In the exploratory analysis, the measuring instrument of reliability shows that all items have an item-total correlation above the recommended 0.3 minimum. The Cronbach Alpha in all scales is greater than 0.7 , recommended value by Nunnally (1979), which indicates adequate internal consistency. With regard to the unidimensionality analysis, their results did not lead to removal of any item; in all cases the factor loadings are greater than 0.5 and the accumulated percentage of explained variance is greater than $50 \%$ in each of the scales. 
In the confirmatory factor analysis of the scales, we examined the measurement model, the structural model and the overall model, which guarantees the validity and reliability of the measurement scales, debugging the model if necessary. As shown in Table 2, the models have good measures of absolute, incremental fit and parsimony, all indicators show values within the generally accepted limits and the probability associated with c2 is above the recommended 0.05.

The reliability measured by average variance (AV) and composite reliability (CR) has, in all cases, values higher than 0.5; in the case of $\mathrm{AV}$ and $\mathrm{CR}$, values are above the minimum recommended 0.7. Finally, the validity of the concept is studied from the convergent validity perspective, which is demonstrated, as the factor loadings are statistically significant (Student t> + - 1.96, Anderson \& Gerbing, 1988) and also the standardized factor loadings are greater than $\beta>0.50$ (Hildebrandt, 1987) (Table 2).

With respect to Discriminant Validity (which allows us to also check the unidimensionality of the constructs), for its verification, we reviewed the estimates of the correlations between the different latent factors, noting that the correlations are not higher than 0.5 , so we can assume that it exists and there is no need for further testing.

Table 2

Results of the confirmatory factor analysis

\begin{tabular}{|c|c|c|c|}
\hline Paths & 凶 & AV & CR \\
\hline Leadership $(\boldsymbol{a}=0.948)$ & & 0.58 & 0.84 \\
\hline LE2 & 0.887 & & \\
\hline LE3 & 0.925 & & \\
\hline LE4 & 0.623 & & \\
\hline LE5 & 0.950 & & \\
\hline LE7 & 0.760 & & \\
\hline \multicolumn{4}{|c|}{$\chi^{2}(\mathrm{df} 5)=7.989(\mathrm{p}=0.157), \mathrm{GFI}=0.969, \mathrm{AGFI}=0.908, \mathrm{CFI}=0.993, \mathrm{RMSEA}=0,978, \chi^{2} \operatorname{Normalized}\left(\chi^{2} / \mathrm{df}\right)=1.598$} \\
\hline Quality Policy and strategy $(\mathbf{a}=\mathbf{0 . 9 3 3})$ & & 0.50 & 0.83 \\
\hline PO1 & 0.633 & & \\
\hline PO3 & 0.913 & & \\
\hline PO4 & 0.618 & & \\
\hline PO5 & 0.917 & & \\
\hline PO6 & 0.838 & & \\
\hline \multicolumn{4}{|c|}{$\chi^{2}(\mathrm{df} 9)=7.754(\mathrm{p}=0.70), \mathrm{GFI}=0.967, \mathrm{AGFI}=0.901, \mathrm{CFI}=0.991, \mathrm{RMSEA}=0.075, \chi^{2}$ Normalized $\left(\chi^{2} / \mathrm{df}\right)=1.551$} \\
\hline Personnel Management $(a=0.960)$ & & 0.55 & 0.88 \\
\hline PM2 & 0.854 & & \\
\hline PM4 & 0.934 & & \\
\hline PM6 & 0.873 & & \\
\hline PM7 & 0.907 & & \\
\hline PM9 & 0.778 & & \\
\hline PM11 & 0.758 & & \\
\hline \multicolumn{4}{|c|}{$\chi^{2}(\mathrm{df} 9)=15.770(\mathrm{p}=0.072), \mathrm{GFI}=0.953, \mathrm{AGFI}=0.889, \mathrm{CFI}=0.987, \mathrm{RMSEA}=0.087, \chi^{2}$ Normalized $\left(\chi^{2} / \mathrm{df}\right)=1.752$} \\
\hline Learning $(\boldsymbol{a}=0.937)$ & & 0.52 & 0.78 \\
\hline LA1 & 0.987 & & \\
\hline LA3 & 0.838 & & \\
\hline LA4 & 0.873 & & \\
\hline LA6 & 0.865 & & \\
\hline$\chi^{2}(\mathrm{df} 2)=5.641(\mathrm{p}=0.060), \mathrm{GFI}=0.972$ & $=0.088$ & f) $=2$ & \\
\hline
\end{tabular}




\begin{tabular}{lc}
\hline Process Management $(\boldsymbol{a}=\mathbf{0 . 9 3 7})$ & 0.57 \\
P1 & 0.710 \\
P2 & 0.754 \\
P3 & 0.995 \\
P4 & 0.506 \\
$\chi^{2}(\mathrm{df} 5)=4.052(\mathrm{p}=0.132), \mathrm{GFI}=0.980, \mathrm{AGFI}=0.902, \mathrm{CFI}=0.988, \mathrm{RMSEA}=0.102, \chi^{2}$ Normalized $\left(\chi^{2} / \mathrm{df}\right)=2.026$ \\
\hline Society Results $(\boldsymbol{a}=\mathbf{0 . 8 9 2})$ & 0.65 \\
SR5 & 0.899 \\
SR6 & 0.980 \\
SR7 & 0.938 \\
SR8 & 0.652 \\
& \\
$\chi 2(\mathrm{df} 2)=3.576(\mathrm{p}=0.167), \mathrm{GFI}=0.982, \mathrm{AGFI}=0.912, \mathrm{CFI}=0.996, \mathrm{RMSEA}=0.089, \chi 2 \mathrm{Normalized}(\chi 2 / \mathrm{df})=1.788$ \\
\hline
\end{tabular}

Note. ${ }^{\mathrm{A}}$ The names of the items listed in this Table have been shortened in order to simplify the results. $\beta$ : standard regression weight; a reliability (Cronbach's a); CR: composite reliability; AV: average variance;

\subsection{Structural model}

The standardized coefficients $(\beta)$ indicating the weights of the direct effects of a construct over another one and the direction, as seen in Figure 2 , are significant at $\mathrm{p}<0.05$ level, or at $\mathrm{p}<0.001$. The goodness of fit indices of the model show a good fit of the model. All indices are within acceptable limits and above the minimum values recommended in the literature (Hair et al., 1999; Jöreskog \& Söbom, 1988).

H3 hypothesis that posed the causal relationship between leadership and learning was not supported statistically by significant standardized coefficients $(\beta)(t>+-1.96)$. The $\mathrm{R}^{2}$ measure that indicates the amount of variance of the constructs, which is explained by the model, is low in the case of Society Results (11.6\%).

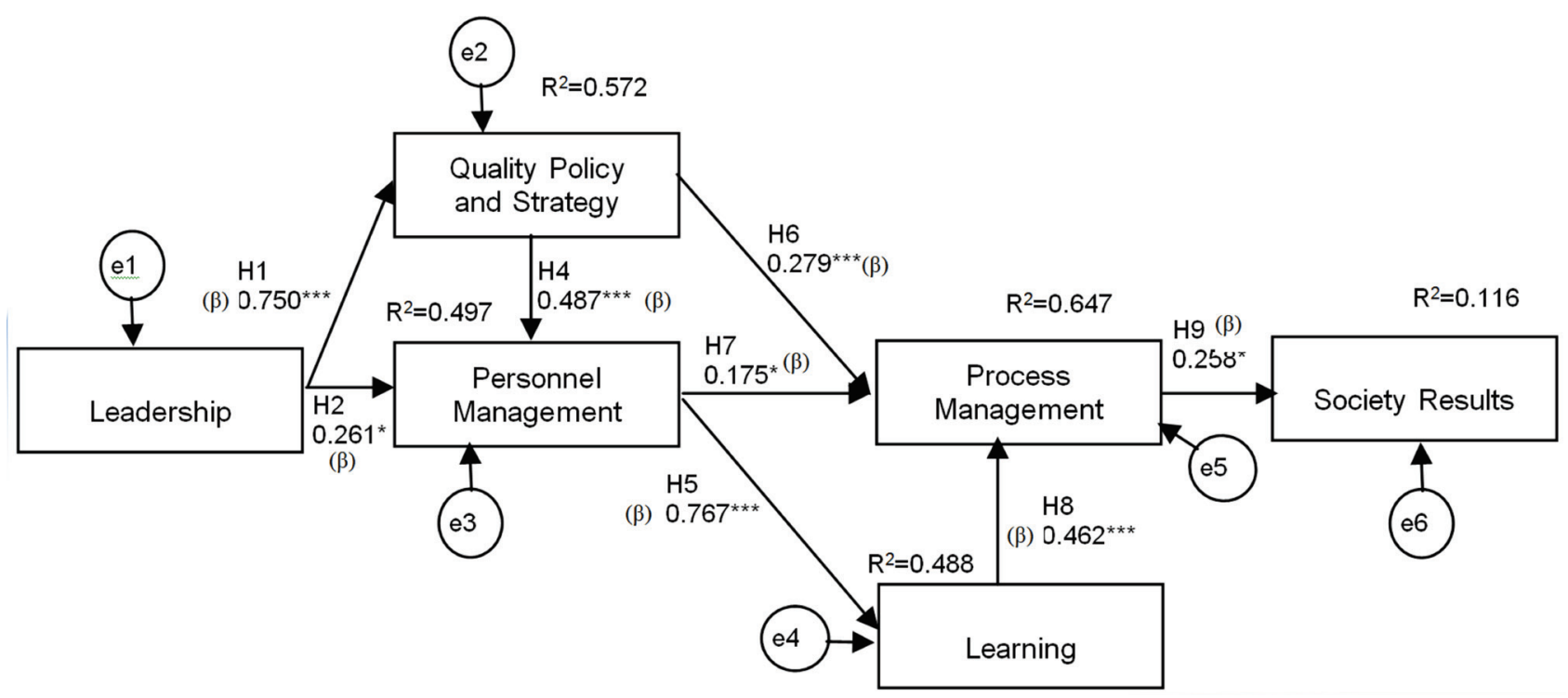

Figure 2. Diagram of the final structural model

Note. ${ }^{*} \mathrm{p}<0.05 ;{ }^{* * *} \mathrm{p}<0.001$

$\chi^{2}(\mathrm{df} 7)=11.332(\mathrm{p}=0.125), \mathrm{GFI}=0.965, \mathrm{AGFI}=0.895, \mathrm{CFI}=0.987, \mathrm{RMSEA}=0.079, \chi^{2} \operatorname{Normalized}\left(\chi^{2} / \mathrm{df}\right)=1.619$

(b) all standardized coefficients indicate a positive relationship 
Finally, we examined the effects (direct and indirect) of the constructs included in the model on Society Results (Table 3).

Table 3

Direct, indirect and total effects on employee management/satisfaction

\begin{tabular}{|c|c|c|c|c|c|c|c|}
\hline Effects & & & 2. & 3. & 4. & 5. & 6.* \\
\hline \multirow[t]{3}{*}{1} & \multirow[t]{3}{*}{ Leadership } & Direct & 0.750 & 0.261 & - & - & - \\
\hline & & Indirect & - & 0.365 & 0.481 & 0.541 & 0.139 \\
\hline & & Total & 0.750 & 0.627 & 0.481 & 0.541 & 0.139 \\
\hline \multirow[t]{3}{*}{2} & \multirow{3}{*}{$\begin{array}{l}\text { Quality policy and } \\
\text { strategy }\end{array}$} & Direct & - & 0.487 & - & 0.279 & - \\
\hline & & Indirect & - & - & 0.374 & 0.258 & 0.138 \\
\hline & & Total & - & 0.487 & 0.374 & 0.537 & 0.138 \\
\hline \multirow[t]{3}{*}{3} & \multirow[t]{3}{*}{ Personnel management } & Direct & - & - & 0.767 & 0.175 & - \\
\hline & & Indirect & - & - & - & 0.354 & 0.136 \\
\hline & & Total & - & - & 0.767 & 0.529 & 0.136 \\
\hline \multirow[t]{3}{*}{4} & \multirow[t]{3}{*}{ Learning } & Direct & - & - & - & 0.462 & - \\
\hline & & Indirect & - & - & - & - & 0.119 \\
\hline & & Total & - & - & - & 0.462 & 0.119 \\
\hline \multirow[t]{3}{*}{5} & \multirow[t]{3}{*}{ Process management } & Direct & - & - & - & - & 0.258 \\
\hline & & Indirect & - & - & - & - & - \\
\hline & & Total & - & - & - & - & 0.258 \\
\hline
\end{tabular}

Note. * Society Results

\section{Discussion}

In recent years, several empirical studies have tried to analyze the relationship between the critical factors in the EFQM model called enablers and the results, which are contained in the EFQM model and are results in customers, employees, society and key results (Bou-Llusar, Escrig-Tena, Roca-Puig, \& Beltrán-Martín, 2005, 2009; Calvo-Mora, Leal, \& Roldán, 2005; Chinda \& Mohamed, 2007; Eskildsen \& Dahlgaard, 2000; Eskildsen, Kristensen, \& Jørn Juhl, 2001, among others). In general, they study the overall relationship with each of the collected results (enablers with results), with few studies analyzing the individual relationship with society results.

The results of the structural model proposed (Table 4) show that there is a relationship between the critical factors of quality and society results in the field of rural housing, but it is weak. It can be observed that there is a direct influence between process management and society results, being antecedents of such relationship quality policy and strategy, personnel management, learning managed by effective leadership and a visible commitment to implementation of quality by the management. 
Table 4

Structural model results

\begin{tabular}{|c|c|c|c|}
\hline Critical factors & $\begin{array}{l}\mathrm{B} \text { (standard } \\
\text { regression weight) }\end{array}$ & Hypotheses & Studies supporting the hypothesis \\
\hline $\begin{array}{l}\text { Leadership à Quality Policy and } \\
\text { Strategy }\end{array}$ & $0.750^{* * *}$ & $\begin{array}{l}\mathrm{H} 1 \\
\text { corroborated }\end{array}$ & $\begin{array}{l}\text { Samson and Terziovski (1999), Eskildsen and Dahlgaard } \\
\text { (2000), Lee, Rho and Lee (2003), Calvo-Mora et al. } \\
\text { (2005), Chinda and Mohamed (2007), Moon, Lee, } \\
\text { Yong-Seung and Suh (2011), Savic Djordjevic, Nikolic, } \\
\text { Mihajlovic, I. and Zivkovic (2013) }\end{array}$ \\
\hline Leadership à Personnel Management & $0.261^{*}$ & $\begin{array}{l}\mathrm{H} 2 \\
\text { corroborated }\end{array}$ & $\begin{array}{l}\text { Flynn et al. (1995), Samson and Terziovski (1999), } \\
\text { Eskildsen and Dahlgaard (2000), Calvo-Mora et al. } \\
\text { (2005), Chinda and Mohamed (2007), Moon et al. } \\
\text { (2011), Savic et al. (2013) }\end{array}$ \\
\hline Leadership à Learning & not significant & $\mathrm{H} 3$ rejected & Result opposed to Tarí et al. (2007) \\
\hline $\begin{array}{l}\text { Quality Policy and Strategy à } \\
\text { Personnel Management }\end{array}$ & $0.487^{* * *}$ & $\begin{array}{l}\mathrm{H} 4 \\
\text { corroborated }\end{array}$ & $\begin{array}{l}\text { Samson and Tterziovski (1999), Eskildsen and } \\
\text { Dahlgaard (2000), Lee et al. (2003), Calvo-Mora et } \\
\text { al. (2005), Tarí et al. (2007) }\end{array}$ \\
\hline Personnel Management à Learning & $0.767^{* * *}$ & $\begin{array}{l}\mathrm{H} 5 \\
\text { corroborated }\end{array}$ & $\begin{array}{l}\text { Samson and Tterziovski (1999), Eskildsen and } \\
\text { Dahlgaard (2000), Lee et al. (2003), Calvo de Mora et } \\
\text { al. (2005), Tarí et al. (2007) }\end{array}$ \\
\hline $\begin{array}{l}\text { Quality Policy and Strategy } \rightarrow \text { Process } \\
\text { Management }\end{array}$ & $0.279^{* * *}$ & $\begin{array}{l}\text { H6 } \\
\text { corroborated }\end{array}$ & \multirow{3}{*}{$\begin{array}{l}\text { Eskildsen and Dahlgaard (2000), Calvo-Mora et al. } \\
\text { (2005), Chinda and Mohamed (2007) and Tarí et al. } \\
\text { (2007) }\end{array}$} \\
\hline $\begin{array}{l}\text { Personnel Management à Process } \\
\text { Management }\end{array}$ & $0.175^{*}$ & $\begin{array}{l}\text { H7 } \\
\text { corroborated } \\
\end{array}$ & \\
\hline Learning à Process Management & $0.462^{* * *}$ & $\begin{array}{l}\mathrm{H} 8 \\
\text { corroborated }\end{array}$ & \\
\hline Process Management à Society Results & $0.258^{*}$ & $\begin{array}{l}\mathrm{H} 9 \\
\text { corroborated }\end{array}$ & Bou-Llusar et al. (2005), Tarí et al. (2007) \\
\hline
\end{tabular}

Note. ${ }^{*} \mathrm{p}<0.05 ;{ }^{* * *} \mathrm{p}<0.001$

All the hypotheses proposed in the model are empirically validated by significant standardized coefficients, except for the relationship between leadership and learning (H3) that is lost, result opposed to the one obtained by Tarí et al. (2007). This result may be because in the rural housing sector the number of employees is very limited, so leadership is not important for establishing the quality policy and planning and personnel management practices, and does not directly influence the learning process, which is influenced by personnel management.

In the literature reviewed, we found studies supporting each of the hypotheses that have been empirically validated in this study. The positive relationship between leadership and quality policy and strategy (H1) is corroborated by studies of Samson and Terziovski (1999), Eskildsen and Dahlgaard (2000), Lee, Rho and Lee (2003), Calvo-Mora et al. (2005), Chinda and Mohamed (2007), Moon, Lee, Yong-Seung and Suh (2011) and Savic et al. (2013). The H2 hypothesis posed by the positive relationship between leadership and personnel management is supported by Flynn et al. (1995), Samson and Terziovski (1999), Eskildsen and Dahlgaard (2000), Calvo-Mora et al. (2005), Chinda and Mohamed (2007), Moon et al. (2011), Savic et al. (2013).

On the other hand, results show that the antecedents of process management are quality policy and strategy (H6), personnel management (H7) and learning (H8), which have a direct and positive effect on process management. These results are corroborated by Eskildsen and Dahlgaard (2000), Calvo-Mora et al. (2005), Chinda and Mohamed (2007) and Tarí et al. (2007). There is also a relationship of interdependence between policy and planning and employee management (H4) and the latter 
with learning (H5), which is consistent with other studies (Calvo De Mora et al., 2005; Eskildsen \& Dahlgaard, 2000; Lee et al., 2003; Samson \& Terziovski, 1999; Tarí et al., 2007). Finally, the relationship between process management and society results (H9) is globally supported by studies of Bou-Llusar et al. (2005) and Tarí et al. (2007).

Finally, the results obtained suggest that process management is the only quality practice that has a direct effect on society results ( $\beta=0.258)$, with the largest total effect on this result. The explained variance of the variable $\left(R^{2}=\right.$ 0.116 ) indicates that the variables included in the model explain $11.6 \%$ of society results.

\section{Conclusions}

This study complements previous studies carried out to analyze the influence of TQM implementation on society results, as the results are contradictory. Several research studies have shown that quality management does not always improve sustainability of a company (BenavidesVelasco, Quintana-García, \& Marchante-Lara, 2014; Viada-Stenberg, Balbastre-Benavent, \& Redondo-Cano, 2010), however, others like McAdam and Leonard (2003), Withanachchi et al. (2007) and Zink (2007) state that TQM implementation can produce changes in the organizational culture, which facilitates the incorporation of the objectives and practices of Corporate Social Responsibility (CSR). In this sense, Withanachchi et al. (2007) state that it can facilitate the development of socially responsible activities and, for Curkovic (2003), it facilitates the development of environmental management. Management of the critical factors in the EFQM Excellence Model is designed to favor the implementation of Corporate Social Responsibility by aiming at effective employee management, concern for environmental management, transparency in operations, etc. It enables progress in the seven fundamental issues found in the ISO 26000:2012. It is a guide on responsibility and gaining competitive advantages in the long term, which will enable excellence achievement by being socially responsible.

Therefore, the contribution of this study, which explores the impact of the critical factors of quality on society results, is to confirm that there is an effect of the critical factors of quality on society results (social and environmental responsibilities) through the direct relationship of process management with social impact results. In this sense, very few studies examine this relationship. Previous studies comprehensively analyzed the relationship with the four results of the EFQM model, so with this research we want to complete the scientific literature and support one of the two contradictory approaches we have mentioned. The results were validated statistically and show that quality influences the society results variable, although this impact is very weak, while there are no other explanatory variables in the model. This result is corroborated by the results obtained in studies by McAdam and Leonard (2003) and Withanachchi et al. (2007) who argue that quality practices can facilitate the development of CSR.

Therefore, we believe that, like Tarí and García (2011) and Benavides-Velasco et al. (2014), Quality Management implementation favors the implementation of social responsibility actions (environmental and social), and is necessary the more the company fosters a CSR culture and implements this philosophy, integrating social and environmental concerns in the strategy and operations of the organization. As Benavides-Velasco et al. (2014, p. 77) mentioned, “Total Quality Management (TQM) and Corporate Social Responsibility (CSR) are relevant management philosophies in the hotel industry to create a sustainable competitive advantage" and "complementarity of both philosophies can improve development of CSR”. However, they note that TQM is a philosophy implemented in many enterprises in the tourism sector, however, CSR implementation is more recent in this sector. (Alonso-Almeida et al., 2012; Kang et al., 2010).

In their study they demonstrated empirically that there is no direct influence of 
quality management on the level of satisfaction of society, which would be more influenced by the implementation of CSR activities. However, "the level of development of CSR would be positively influenced by TQM implementation" (BenavidesVelasco et al., 2014, p. 84).

On the other hand, we are especially interested in highlighting the results specifically obtained in this sector of great importance for tourism today, in addition to the contribution to the scientific literature previously mentioned. They also allow us to extract an important practical application for the sector. Thus, managers of the establishments should be aware that the implementation of a Quality Management System is the first step to obtaining society results in the sense that, as already mentioned, favors the implementation of social responsibility actions, although this is not enough to achieve optimum results, but otherwise rural accommodation establishments must create a culture of CSR within the company.

This study presents the inherent limitations of most researches: (1) study of a sector with specific characteristics, rural housing sector, and data from a particular moment in time (longitudinal design), the generalization of the findings should be made with caution and always from a previous analysis of the characteristics of the population to be considered; (2) the questionnaires were responded by quality managers, which is a bias in the investigation, limitation which can be solved by involving all human resources of the organization (middle management, staff) in data collection; (3) number of responses, which is quite limited for the number of items, but it was a difficult overcome by limiting the number of subjects of the population. We considered that conducting the study despite this limitation is important due to the growing importance this sector today (tourism, number of jobs, regional development of rural areas, etc.), and it is very important to deepen the knowledge in this field of study in this sector, using advanced statistical techniques. Therefore, we investigated about current recommendations on the sample size and the number of items. We believe that, with certain limitations, the study meets the requirements of the minimum sample size needed, taking into account the new studies that exist about the number of responses, population size, to obtain accurate estimates of the coefficients in the EFA (Lloret-Segura, Ferres-Traver, Hernández-Baeza, \& Tomás-Marco, 2014).

\section{References}

Ahire, S. L., Golhar, D. Y., \& Waller, M. A. (1996). Development and validation of TQM implementation constructs. Decision Sciences, 27(1), 23-56.

Ahmad, S., \& Schroeder, R. G. (2002). The importance of recruitment and selection process for sustainability of total quality management. International Journal of Quality \& Reliability Management, 19(5), 540-550.

Alonso-Almeida, M. D. M., Rodríguez-Antón, J. M., \& Rubio-Andrada, L. (2012). Reasons for implementing certified quality systems and impact on performance: An analysis of the hotel industry. The Service Industries Journal, 32(6), 919-936.

ALNasser, A., Yusoff, R. Z., \& Islam, R. (2013). Relationship between hard total quality management practices and organizational performance in municipalities. American Journal of Applied Sciences, 1O(10), 1214-1223.

Al-Tarawneh, H. A. (2010). Total Quality management and leadership an experimental investigation of ISO certified companies in Jordan. Interdisciplinary Journal of Contemporary Research in Business, 2(1), 382-398.

Anderson, J. C., \& Gerbing, D. W. (1988). Structural equation modeling in practice: A review and recommended two-step approach. Psychological Bulletin, 103(3), 411-423. 
Anderson, J. C., Rungtusanatham, M., \& Schroeder, R. G. (1994). A theory of quality management underlying the Deming management method. Academy of Management Review, 19(3), 472-509.

Bagozzi, R. Y. B., \& Baumgartner, P. J. H. (1994). The evaluation of structural equation models and hypothesis testing. In R. Y. B. Bagozzi (Ed.), Principles of Marketing Research (pp. 386-422). Cambridge: Blackwell Business.

Barrett, B., \& Waddell, D. (2001, February). Quality culture and its impact on quality performance. Proceedings of the International and National Research Conference on Quality and Innovation Management, Sidney, Australia, 5., 8., pp. 1-11.

Benavides-Velasco, C. A., Quintana-García, C., \& Marchante-Lara, M. (2014). Total quality management, corporate social responsibility and performance in the hotel industry. International Journal of Hospitality Management, 41, 77-87.

Black, S. A., \& Porter, L. J. (1996). Identification of the Critical Factors of TQM*. Decision Sciences, 27(1), 1-21.

Bou-Llusar, J., Escrig-Tena, A. B., Roca-Puig, V., \& Beltrán-Martín, I. (2005). To what extent do enablers explain results in the EFQM excellence model? An empirical study. International Journal of Quality \& Reliability Management, 22(4), 337-353.

Bou-Llusar, J. C., Escrig-Tena, A. B., Roca-Puig, V., \& Beltrán-Martín, I. (2009). An empirical assessment of the EFQM Excellence Model: Evaluation as a TQM framework relative to the MBNQA Model. Journal of Operations Management, 27(1), 1-22.

Browne, M. W., \& Cudeck, R. (1993). Alternative ways of assessing model fit. In K. A. Bollen, \& J. S. Long (Eds.), Testing structural equation models (pp. 1136-162). Newbury Park, CA: Sage.

Calvo-Mora, A., Leal, A., \& Roldán, J. L. (2005). Relationships between the EFQM model criteria: a study in Spanish universities. Total Quality Management \& Business Excellence, 16(6), 741-770.

Caneda, M. C. (2004). La responsabilidad social corporativa interna: La "nueva frontera" de los recursos humanos. Madrid: Esic Editorial.

Chang, C. C., Chiu, C. M., \& Chen, C. A. (2010). The effect of TQM practices on employee satisfaction and loyalty in government. Total Quality Management, 21(12), 1299-1314.

Chinda, T., \& Mohamed, S. (2007). Causal relationships between enablers of construction safety culture. Proceedings of the international conference on construction in 21st century: Accelerating Innovation in Engineering, Management and Technology, Gold Coast, Australia, 4.

Comisión de Las Comunidades Europeas (2001). Libro verde: Fomentar un marco europeo para la responsabilidad social de las empresas. Retrieved from http://eur-lex.europa.eu/ legal-content/ES/TXT/PDF/?uri=CELEX: 52001DC0366\&from=ES

Cronbach, L. J. (1951). Coefficient alpha and the internal structure of tests. Psychometrika, 16(3), 297-334.

Curkovic, S. (2003). Environmentally responsible manufacturing: The development and validation of a measurement model. European Journal of Operational Research, 146(1), 130-155.

Deming, W. E. (1982). Quality, productivity, and competitive position. Cambridge: Massachusetts Institute of Technology.

Elkington, J. (1997). Cannibals with forks: The triple bottom line of twenty first century business. Mankato, MN: Capstone Publishing. 
Escrig, A. (2010). La sostenibilidad en el Modelo EFQM de Excelencia. In L. Rivero (Coord.), Gestión de la RSC (pp. 77-112). A Coruña: Ed. Netbiblo.

Eskildsen, J. K., \& Dahlgaard, J. J. (2000). A causal model for employee satisfaction. Total Quality Management, 11(8), 1081-1094.

Eskildsen, J. K., Kristensen, K., \& Jørn Juhl, H. (2001). The criterion weights of the EFQM excellence model. International Journal of Quality \& Reliability Management, 18(8), 783-795.

Eskildsen, J. K., Kristensen, K., \& Jørn Juhl, H. (2002). Trends in EFQM criterion weights; the case of Denmark 1998-2001. Measuring Business Excellence, 6(2), 22-28.

European Foundation for Quality Management. (1999). EFQM Model for Business Excellence: Company Guidelines. Bruselas: EFQM.

European Foundation for Quality Management. (2004). EFQM Framework for Corporate Social Responsibility. Bruselas: EFQM.

European Foundation for Quality Management. (2013). EFQM Model for Business Excellence: Company Guidelines. Bruselas: EFQM.

Flynn, B. B., Schroeder, R. G., \& Sakakibara, S. (1995). The impact of quality management practices on performance and competitive advantage. Decision Sciences, 26(5), 659-691.

Fotopoulos, C. B., \& Psomas, E. L. (2009). The impact of "soft" and "hard" TQM elements on quality management results. International Journal of Quality \& Reliability Management, 26(2), 150-163.

Grandzol, J. R., \& Gershon, M. (1998). A survey instrument for standardizing TQM modeling research. International Journal of Quality Science, 3(1), 80-105.

Grover, S., Agrawal, V.P ., \& Khan, I. A. (2006). Role of human factors in TQM: A graph theoretic approach. Benchmarking: An International Journal, 13(4), 447-468.

Hackman, J. R., \& Wageman, R. (1995). Total quality management: Empirical, conceptual, and practical issues. Administrative Science Quarterly, 40(2), 309-342.

Hair, J., Anderson, R., Tathaman, R., \& Black, W. (1999). Análisis multivariante (5th ed.). Madrid: Prentice Hall.

Hair, J., Jr., Sarstedt, M., Hopkins, L., \& Kuppelwieser, V. (2014). Partial least squares structural equation modeling (PLS-SEM) An emerging tool in business research. European Business Review, 26(2), 106-121.

Hassan, M., \& Kerr, R. M. (2003). The relationship between total quality management practices and organisational performance in service organisations. The TQM Magazine, 15(4), 286-291.

Hietschold, N., Reinhardt, R., \& Gurtner, S. (2014). Measuring critical success factors of TQM implementation successfully-a systematic literature review. International Journal of Production Research, 52(21), 6254-6272.

Hildebrandt, L. (1987). Consumer retail satisfaction in rural areas: A reanalysis of survey data. Journal of Economic Psychology, 8(1), 19-42.

Holjevac, I. A. (2008). Business ethics in tourismas a dimension of TQM. Total Quality Management \& Business Excellence, 19(10), 1029-1041.

Joreskog, K. G., \& Söbom, D. (1993). Prelis: a preprocessor for LISREL. Mooresville, Ind: Scientific Software.

Juran, J. M. (1988). Juran on planning for quality. New York: Free Press.

Kang, K. H., Lee, S., \& Huh, C. (2010). Impacts of positive and negative corporate social responsibility activities on company 
performance in the hospitality industry. International Journal of Hospitality Management, 29(1), 72-82.

Lakhal, L., Pasin, F., \& Limam, M. (2006). Quality management practices and their impact on performance. International Journal of Quality \& Reliability Management, 23(6), 625-646.

Lee, S. M., Rho, B. H., \& Lee, S. G. (2003). Impact of Malcolm Baldrige National Quality Award criteria on organizational quality performance. International Journal of Production Research, 41(9), 2003-2020.

Lloret-Segura, S., Ferreres-Traver, A., HernándezBaeza, A., \& Tomás-Marco, I. (2014). El análisis factorial exploratorio de los ítems: Una guía práctica, revisada y actualizada. Anales de Psicología, 30(3), 1151-1169.

Magd, H. A. (2014). TQM Constructs Development and Validation in the context of Egyptian Manufacturing Sector: A snapshot Perspective. Proceedings of the International Conference on ISO \& TQM, Kuching, Malasya, 18. 7.1DK.

Marimon Viadiu, F., Casadesús Fa, M., \& Heras Saizarbitoria, I. (2006). ISO 9000 and ISO 14000 standards: An international diffusion model. International Journal of Operations \& Production Management, 26(2), 141-165.

McAdam, R., \& Leonard, D. (2003). Corporate social responsibility in a total quality management context: opportunities for sustainable growth. Corporate Governance: The International Journal of Business in Society, 3(4), 36-45.

Moon, J. Y., Lee, S. C., Yong-Seung, P., \& Suh, Y. H. (2011). A study on the causal relationships in the Korean National Quality Award model. Total Quality Management \& Business Excellence, 22(7), 705-726.

Nabitz, U., Severens, P., Van Den Brink, W., \& Jansen, P. (2001). Improving the EFQM
Model: An empirical study on model development and theory building using concept mapping. Total Quality Management, 12(1), 69-81.

Nair, A. (2006). Meta-analysis of the relationship between quality management practices and firm performance-implications for quality management theory development. Journal of Operations Management, 24(6), 948-975.

Norris, G., \& O’Dwyer, B. (2004). Motivating socially responsive decision making: The operation of management controls in a socially responsive organisation. The British Accounting Review, 36(2), 173-196.

Nunnally, J. (1979). Psychometric theory. New York: McGraw-Hill.

Pannirselvam, G. P., \& Ferguson, L. A. (2001). A study of the relationships between the Baldrige categories. International Journal of Quality \& Reliability Management, 18(1), 14-37.

Pedersen, E., \& Neergaard, P. (2008). From periphery to center: How CSR is integrated in mainstream performance management frameworks. Measuring Business Excellence, 12(1), 4-12.

Powell, T. C. (1995). Total quality management as competitive advantage: A review and empirical study. Strategic Management Journal, 16(1), 15-37.

Rao, S. S., Solis, L. E., \& Raghunathan, T. S. (1999). A framework for international quality management research: development and validation of a measurement instrument. Total Quality Management, 10(7), 1047-1075.

Robson, A., \& Mitchell, E. (2007). CSR performance: driven by TQM implementation, size, sector? International Journal of Quality \& Reliability Management, 24(7), 722-737. 
Sadikoglu, E., \& Zehir, C. (2010). Investigating the effects of innovation and employee performance on the relationship between total quality management practices and firm performance: An empirical study of Turkish firms. International Journal of Production Economics, 127(1), 13-26.

Samson, D., \& Terziovski, M. (1999). The relationship between total quality management practices and operational performance. Journal of Operations Management, 17(4), 393-409.

Saraph, J. V., Benson, P. G., \& Schroeder, R. G. (1989). An instrument for measuring the critical factors of quality management. Decision Sciences, 20(4), 810-829.

Savic, M., Djordjevic, P., Nikolic, D., Mihajlovic, I., \& Zivkovic, Z. (2013). Modeling the influence of EFQM criteria on employee's satisfaction and loyalty in transition economy: The study of banking sector in Serbia. Serbian Journal of Management, 9(1), 15-30.

Sharma, S. (1996). Applied multivariate techniques. New York: John Wiley\& Sons.

Singh, P. J., Feng, M., \& Smith, A. (2006). ISO 9000 series of standards: Comparison of manufacturing and service organisations. International Journal of Quality \& Reliability Management, 23(2), 122-142.

Sila, I., \& Ebrahimpour, M. (2002). An investigation of the total quality management survey based research published between 1989 and 2000: A literature review. International Journal of Quality \& Reliability Management, 19(7), 902-970.

Soltani, E., Lai, P. C., \& Gharneh, N. S. (2005). Breaking through barriers to TQM effectiveness: Lack of commitment of upperlevel management. Total Quality Management and Business Excellence, 16(8-9), 1009-1021.

Talib, F., Rahman, Z., \& Qureshi, M. N. (2013). An empirical investigation of relationship between total quality management practices and quality performance in Indian service companies. International Journal of Quality \& Reliability Management, 30(3), 280-318.

Tarí, J. J., \& García M. G. (2011). La gestión de la calidad y la responsabilidad social en empresas de servicios. Revista de Dirección y Administración de Empresas, (18), 77-94.

Tari, J. J., Molina, J. F., \& Castejon, J. L. (2007). The relationship between quality management practices and their effects on quality outcomes. European Journal of Operational Research, 183(2), 483-501.

Viada-Stenger, M. C., Balbastre-Benavent, F., \& Redondo-Cano, A. M. (2010). The implementation of a quality management system based on the $Q$ tourist quality standard. The case of hotel sector. Service Business, 4(3-4), 177-196.

Vidal Vázquez, E., \& Soto Rodríguez, E. (2013). Principles of CSR on models of excellence. In J. A. C. Santos, P. Águas, \& F. P. Ribeiro (Eds.), Strategic management, entrepreneurship o innovation (pp. 1122-1133, 4 Vol.). Faro: Universidade do Algarve.

Wilson, D. D., \& Collier, D. A. (2000). An empirical investigation of the Malcolm Baldrige National Quality Award causal model. Decision Sciences, 31(2), 361-383.

Winn, B. A., \& Cameron, K. S. (1998). Organizational quality: An examination of the Baldrige National Quality Award causal model. Decision Sciences, 39(5), 491-512.

Withanachchi, N., Handa, Y., Karandagoda, K. K. W., Pathirage, P. P., Tennakoon, N. C. K., \& Pullaperuma, D. S. P. (2007). TQM emphasizing 5-S principles: A breakthrough for chronic managerial constraints at public hospitals in developing countries. International Journal of Public Sector Management, 20(3), 168-177.

Yusof, S. R. M., \& Aspinwall, E. (2000). Critical 
success factors for total quality management implementation in small and medium enterprises. Total Quality Management, 10(45), 803-809.

Zairi, M. (1996). Competition: what does it mean? The TQM Magazine, 8(1), 54-59.

Zhang, Z., Waszink, A. B., \& Wijngaard, J. (2000). An instrument for measuring TQM implementation for Chinese manufacturing companies. International Journal of Quality \& Reliability Management, 17(7), 730-755.

Zink, K. J. (2007). From total quality management to corporate sustainability based on a stakeholder management. Journal of Management History, 13(4), 394-401.

\section{Appendix: Measurement scales}

Leadership (Black \& Porter, 1995; Powell, 1995; Grandzol \& Gershon, 1998; EFQM model, 1999)

LE1-Top management actively manages our quality program and reviews its effectiveness once implemented

LE2-Administrators actively communicate a quality commitment to employees

LE3-Employees are encouraged to help implement changes in the organization

LE4-The Management team allows employees to make their own decisions

LE5-The management team motivates its employees and helps them to fulfill their work at a high level

LE6-The Management appreciates the efforts and improvements made by the staff

LE7-The Management maintains contacts with customers, suppliers and other external agents and is involved with them in the promotion and participation of alliances and improvement actions

LE8-The changes that should be carried out for improvement are identified and boosted by the Management and their effectiveness is reviewed once implemented

Quality Policy and strategy (Saraph, Benson \& Schroeder, 1989; Black \& Porter, 1995; Ahire, Golhar, \& Waller, 1996; EFQM model, 1999)

QP1-Strategies and business plans based on the information about customer requirements and business capabilities are developed and implemented.

QP2-The management displays the policy establishing realistic targets for all its staff (managers and employees)

QP3-The management communicates its strategy and objectives to all staff

QP4-The management communicates its strategy and objectives to customers, suppliers and other external agents in order for them to know them

QP5-Staff is involved in setting objectives and plans

QP6-Key processes are identified and developed from the business strategies or plans

QP7-The results are evaluated by performing a comparison with those planned, with the aim of improvement

Personnel Management (Saraph, Benson \& Schroeder, 1989; Black \& Porter, 1995; Ahire, Golhar, \& Waller, 1996; EFQM model, 1999)

EM1-Management of human resources in line with the strategy and / or business plans is performed

EM2-The management is trained in quality principles

EM3-Employees are trained in quality principles

EM4-Employees are trained in problem-solving skills

EM5-Employees are trained in teamwork

EM6-Experience and training of people is adjusted to current and future needs or specific training plans are developed

EM7-People are encouraged and supported to take responsibility and make decisions without risk for the organization, to be involved in improvement activities, teamwork, etc.

EM8-There is a transparent system to reward staff achievements and improvements, as well as a social benefits system (pension plan,

kindergarten ... etc.)

EM9-Employee performance is measured and recognized in order to motivate them and improve their work performance

EM10-Communication between all personnel is ascending, descending and horizontal, so that employees are considered to be wellinformed and that their opinions are valued

EM11-Improvements in human resource management are introduced by using staff satisfaction surveys, regular meetings with employees, performance analysis, etc.

Learning (Grandzol \& Gershon, 1998)

L1-Managers and supervisors ensure that all employees receive training in order to help them understand how and why the organization performs

L2-Most employees of this company have sufficient knowledge about the basics of the sector

L3-Most employees of this organization understand the basic processes used to create our products / services

L4-All company employees are trained in the concepts of total quality

L5-The company employees are trained in basic statistical tools

L6-Employees receive training to develop teamwork

L7-Availability of resources for staff training within the organization

L8-Top management has established an environment that encourages continuous training

L9-Managers and supervisors participate in specialized training 
Process Management (Saraph, Benson \& Schroeder, 1989; Black \& Porter, 1995; Ahire, Golhar, \& Waller, 1996; Grandzol \& Gershon, 1998; EFQM model, 1999)

PM1-Control and continuous improvement of key processes

PM2-Prevention of defective services is a strong attitude in this organization

PM3-The processes used in this organization include measures to ensure that development of services are consistent with the previous design and subsequent execution (quality measures)

PM4-Employees involved in different processes know how to evaluate them

PM5-New services in an attempt to access other markets are developed, anticipate the needs of today's market or try to be better than the main competitors

PM6-The development of products / services in line with previous designs and later developments is guaranteed

Society Results (EFQM model, 1999)

SR1-Policies to reduce and prevent risks to health and safety are developed

SR2-Environmental protection policies are developed

SR3-The company participates in many community activities

SR4-The feeling the community has is evaluated through surveys, meetings with authorities, etc.

SR5-The results in society show improvements over time

SR6-Objectives in this context are established and the results achieved meet the objectives set by the organization

SR7-The causes of these results in society are analyzed and plans or actions for improvement are implemented

SR8- These results in society are compared with the company's main competitors, being such comparative favorable or otherwise learning from them

\section{About the authors:}

1. María de la Cruz del Río-Rama, PhD in Business Management, University of Vigo, Ourense, Spain. E-mail: delrio@uvigo.es

2. José Álvarez-García, PhD in Tourism Management and Planning, University of Extremadura, Cáceres, Spain. E-mail: pepealvarez@unex.es

3. José Luis Coca-Pérez, PhD in Economic and business Sciences, Universidad Complutense de Madrid, Spain. E-mail: jlcoca@unex.es

\section{Note:}

A preliminary version of this article was presented on XXIV AEDEM International Conference da European Academy of Management and Business Economics (Londres, Reino Unido), held on september 2, 2015..For this version, the article had update parts.

\section{Contribution of each author:}

\section{Contribution} María de la Cruz del Río-Rama José Álvarez-García José Luis Coca-Pérez

1. Definition of research problem

2. Development of hypotheses or research questions (empirical studies)

3. Development of theoretical propositions (theoretical work)

4. Theoretical foundation / Literature review

5. Definition of methodological procedures

6. Data collection

7. Statistical analysis

8. Analysis and interpretation of data

9. Critical revision of the manuscript

10. Manuscript writing

$\begin{array}{lll}\sqrt{ } & \sqrt{ } & \sqrt{ } \\ \sqrt{ } & \sqrt{ } & \sqrt{ } \\ \sqrt{ } & \sqrt{ } & \\ \sqrt{ } & \sqrt{ } & \sqrt{ } \\ \sqrt{ } & \sqrt{ } & \sqrt{ } \\ \sqrt{ } & \sqrt{ } & \\ \sqrt{ } & \sqrt{ } & \\ \sqrt{ } & \sqrt{ } & \sqrt{ } \\ \sqrt{ } & \sqrt{ } & \sqrt{ } \\ \sqrt{ } & \sqrt{ } & \sqrt{ }\end{array}$

